\title{
CONTEMPORARY RECEPTION OF EDDIC THEMES IN NEW MEDIA: VIRTUAL 'NORDIC' IDENTITIES, CASE STUDY: DARK AGE OF CAMELOT
}

\author{
Ester Jiresch and Vincent Boswijk \\ University of Groningen \\ e.jiresch@rug.nl, v.h.boswijk@student.rug.nl
}

\section{Keywords}

National identity, Nordic mythology, cultural studies, imagology, computer games, MMORPG

This article discusses the most recent (twenty-first century) development in reception and adaptation of Nordic mythology (particularly referring to the Prose and Poetic Edda) and the appropriating of Nordic identities (stereotypes) that is taking place in the so-called new media.

In the last two decades the reception of Nordic mythology or Nordic 'themes' in different new media like film, comic books, heavy metal music and computer games has exploded. New media are generally considered expressions of 'popular' culture and have therefore not yet received much scholarly attention. However, since those media are growing notably and especially computer games (console and online applications) reach an enormous audience. Scientific interest in them has increased in recent years.

Miller mentions the 'sexiness of Vikings in video games, the pretense of Viking-like settings for popular television programs [...]' (Miller, 2014, p. 4).

The case study is Dark Age of Camelot (DAoC - Mythic Entertainment 2001) which is a MMORPG (Massive Multiplayer Online Role Playing Game) that is currently (2015) still available to play online. We will show examples of themes (characters, narratives, objects etc.) deriving from Eddic texts and how they are represented and deployed in the game. Since the representation of 'Nordic' identity is a key feature in the game's construction, it will therefore be addressed as well. The fictional world of DAoC consists of three realms - Albion, Hibernia and Midgard - that are at war with each other. Their (human) inhabitants are respectively based on medieval Anglo-Saxon, Celtic and Norse tribes that differ distinctively in their character traits. Our goal is to elaborate on the representation of identity traits of the fictional 'Norse' races (as defined by the game) that appear in DAoC. We will scrutinize if and how the game uses older or more current concepts of (national) identity.

In order to do so, an overview of Scandinavian / Nordic identity constructions that have been popular and / or widespread from antiquity will be presented, via medieval sources to romanticism and nineteenth century nationalism until current discussions of national identity.

\section{'Nordic' identity through history}

What follows is a brief overview that is by no means complete, however still providing us with key events, ideas and ideologies that formed standardized self-images (auto-stereotypes) and standardized foreign perceptions (hetero-stereotypes) (Beller \& Leersen, 2008) of Nordic / Scandinavian peoples. 'A stereotype is a generalization about a group of people in which incidental characteristics are assigned to virtually all members of the group, regardless of actual variation among the members. Once formed, stereotypes are resistant to change on the basis of new information' (Aronson, 2005, p. 434 cited in Beller \& Leersen, 2008, p. 429).

Just how resistant to change some of these Nordic stereotypes are, we will examine in the following overview. Since there often were overlapping images (Beller \& Leersen, 2008; Stråth, 1995) of Nordic / Scandinavian identities and respective tribes or nation states this overview comprises a part 'Nordic / Scandinavian' identities and with the limits of this article in mind 'Swedish' identities as representative for one of the modern Scandinavian nation states. Figure 1 shows an overview in key words. 


\begin{tabular}{|c|c|c|}
\hline $\begin{array}{l}\text { Time period / } \\
\text { Source }\end{array}$ & Hetero -stereotypes & Auto-stereotypes \\
\hline \multicolumn{3}{|l|}{ Antiquitity } \\
\hline $\begin{array}{l}\text { Tacitus Germania } \\
\text { (98 A.D.) }\end{array}$ & $\begin{array}{l}\text { SW: Suiones: wealth important (possible link to } \\
\text { medieval alleged Swedish greediness) } \\
\text { Germanic tribes in general: belligerent and } \\
\text { uncivilised, lazy, orderless }\end{array}$ & \\
\hline \multicolumn{3}{|l|}{$\begin{array}{l}\text { Early / High } \\
\text { Middle } \quad \text { Ages } \\
\text { Saga / Viking age } \\
(800-1050)\end{array}$} \\
\hline Old Norse Literature & $\begin{array}{l}\text { SW: Heathen+practising magic 'Dangerous Swede' } \\
\text { sly and greedy, berserk } \\
\text { Exception: Svear as dignity+divine ancestry }\end{array}$ & $\begin{array}{l}\text { Scandinavian sense of community- } \\
\text { 'dọnsk tunga', 'Norðrlond' } \\
\text { Islandic / Norwegian / Danish hero, } \\
\text { smart - superior towards Swedes }\end{array}$ \\
\hline $\begin{array}{l}\text { Adam v. } \text { Bremen } \\
(1075 / 76)\end{array}$ & $\begin{array}{l}\text { SW: Moral integrity, hospitality, fighting abilities } \\
\text { and in contrast to ON material modesty } \\
\text { SC: Generally positive judgement }\end{array}$ & \\
\hline \multicolumn{3}{|c|}{\begin{tabular}{lr|l} 
Late Middle & Ages \\
Kalmar & Union & \\
$(1397-1523)$ &
\end{tabular}} \\
\hline & SC: Strong and brave fighters & $\begin{array}{l}\text { Swedish perspective: tyrannical }+ \\
\text { greedy Danes }\end{array}$ \\
\hline \multicolumn{3}{|l|}{\begin{tabular}{l|l} 
Humanism & $/$ \\
Renaissance \\
Enlightenment
\end{tabular}} \\
\hline $\begin{array}{l}\text { Thirty-Years War } \\
\text { Montesquieu (1748) } \\
\text { Walch (1733) } \\
\text { Völkertafel } \\
\text { (ca. 1730/40): } \\
\text { Krüger (1737) }\end{array}$ & $\begin{array}{l}\text { 'Cruel Swede' } \\
\text { Stronger, more powerful }+ \text { peaceful } \rightarrow \\
\text { Scandinavia as haven of sincerity and freedom } \\
\text { (superior) } \\
\text { SW+DK underdeveloped mental faculties, no } \\
\text { genius, fearfulness and stinginess (se ON sources) } \\
\text { Swede judged ambivalently: 'strong + tall' + 'cruel' } \\
\rightarrow \text { barbarian people } \rightarrow \text { Thirty Years War } \\
\begin{array}{l}\text { Mental deficiency }+ \text { superstition } \rightarrow \text { medieval } \\
\text { notion of pagans }\end{array}\end{array}$ & $\begin{array}{l}\text { SW: Status of military tradition, } \\
\text { judicial and administrative } \\
\text { institutions. Particular praising the } \\
\text { freedom of the Swedish peasantry }\end{array}$ \\
\hline \multicolumn{3}{|l|}{ Romanticism } \\
\hline & & $\begin{array}{l}\text { SW: Götiska förbundet / Gothic } \\
\text { League (1811) } \\
\text { SC: Strong and belligerent viking } \\
\text { Free peasant, close to nature } \rightarrow \\
\text { unity of man and nature }\end{array}$ \\
\hline \multicolumn{3}{|l|}{ Nationalism } \\
\hline & $\begin{array}{l}\text { German } \quad \text { 'Nordenschwärmerei' } \quad \text { 'Noble+proud } \\
\text { savage, blond+blue eyed, healthy+higher race' }\end{array}$ & $\begin{array}{l}\text { Nordic / Scandinavian elements } \\
\text { integrated in resp. national } \\
\text { identities: free peasant, folklighet }\end{array}$ \\
\hline \multicolumn{3}{|l|}{ Twentieth century } \\
\hline & $\begin{array}{l}\text { SC: Model modern welfare states and egalitarian } \\
\text { societies }\end{array}$ & $\begin{array}{l}\text { SC: Model modern welfare states } \\
\text { and egalitarian societies }\end{array}$ \\
\hline
\end{tabular}




\begin{tabular}{|l|l|l|}
\hline & & $\begin{array}{l}\text { SW: 1920ies/30ies building of } \\
\text { folkhem }\end{array}$ \\
\hline 1980ies-now & & $\begin{array}{l}\text { SW: Crisis of the welfare state } \rightarrow \\
\text { frantic search for identity } \\
\text { egalitarian, nature loving, } \\
\text { individualistic, modest, solitary, } \\
\text { shy }\end{array}$ \\
\hline
\end{tabular}

Figure 1

\section{Antiquity}

Since there are no 'indigenous' textual sources of Nordic peoples from Antiquity (with the exceptions of some runic inscriptions that hardly provide self-images of those peoples) we have to look at sources from 'outside' providing us with hetero-images.

One of the oldest Roman sources that tell us about peoples in Northern Europe is Tacitus' De origine et situ Germanorum (98. A.D.), also referred to as Germania. This comprehensive work is a description of many Germanic tribes that inhabited Northern Europe, not only modern Scandinavia. Although Tacitus himself, like many of his colleagues, never visited the area or met the tribes he wrote about, his work became the foundation of a 'Germanic ideology' starting in Humanism (Von See, 2003; Henningsen, 2002). ${ }^{1}$ (See below)

The originally Latin term for Germanic tribes, 'Germani', - first appearing in Julius Caesars De bello Gallico (50 B.C.) - has already in ancient sources been used vastly on many different tribes inhabiting various areas in Northern and Western Europe. It is a term which most likely signifies 'the relatives' or 'the genuine', although never used by any of the Germanic tribes to refer to themselves, unless in contact with the Romans. The confusion and speculation about what 'truly Germanic' means, has been going on in centuries and shall not be discussed in this paper. More often than not it does not refer to images of Scandinavian or Nordic people in particular in the modern understanding. Nevertheless the outer appearance of being blond and blue-eyed that stereotypically describes inhabitants of Northern Europe goes back to ancient sources like Tacitus (Von See, 2003).

In general, he attests that the inhabitants of the north have weak mental capacities, they are belligerent and uncivilised peoples, lazy, incapable of upholding a hierarchical order of society - simply barbaric (Donecker, 2002; Von See 2003; Henningsen, 2002).

A special point of interest for us in Tacitus' Germania is his description of one particular Germanic tribe - the Suiones, a tribe that lived in the area of modern day Swedish Uppland and corresponds to the Old Norse name Svear. The conjunction of 'Svear' and 'rike' (Old Norse 'kingdom') actually turned into the country's name - Sverige (Sweden) (Donecker, 2002; SAOB, 1999).

Tacitus mentioned that wealth was very important to the Suiones, which finds an interesting parallel in high medieval West Norse literature that presents us with a frequent stereotype, according to which Swedes were particularly greedy for gold (see below) (Much, 1959 cited in Donecker, 2002).

\section{Early / High Middle Ages}

The next examined time periods are the Early and High Middle Ages, also referred to as vikingatiden ('viking time') or sagatiden ('saga time') (ca. 800-1050). The term vikingatiden arose firstly in the nineteenth century as result of national romantic endeavours. The term

\footnotetext{
${ }^{1}$ For more information about the appropriation and abuse of imagined 'Germanic' roots in the late nineteenth and early twentieth century in the nation state Germany read Von See, 2003 and also Jiresch, 2013.
} 
sagatiden though dates back to Saxo Grammaticus' Gesta Danorum (ca. 1200) and served much longer as identification for Scandinavian people (Østergård, 1997).

About this period we are told in a great corpus of Scandinavian texts in the Old Norse language, the Icelandic and Norwegian sagas, Scaldic literature and the Eddas (Snorri Sturlusson's (1179-1241) Prose Edda (ca. 1220) and the Poetic Edda (ca. 1270). These texts contain self-images as well as 'inner Nordic' hetero-stereotypes. Furthermore there is a sense of belonging, a supra regional community of the inhabitants of Scandinavia detectable, since they all (Icelanders, Danes, Norwegians and Swedes) would use the same language 'donsk tunga' ('Danish tongue') and would refer to themselves 'inhabitants of the North' living in 'Norðrlond'. Equally important for the identity of medieval Scandinavians were the descent of one of the three kingdoms or the Icelandic republic (Von See, 1999; Müller, 1967 cited in Donecker, 2002; Østergård, 1997).

Due to scarcity (Foote, 1993 cited in Donecker, 2002) of Swedish literature from this age, Swedish self-images are not conveyed, yet an abundance of Swedish hetero-stereotypes from Norwegian and Icelandic texts. That Swedes were the last Scandinavian people to accept that Christianity may have furthered the iterated image of a stupid and heathen people, believing in magic as for example in Orkneyinga saga (ca. 1200) (Orkneyinga saga, 1965 cited in Donecker, 2002). Swedes seem to be generally described in a less flattering way than other Scandinavians. Donecker distinguishes two basic negative stereotypes of people of Swedish descent that appear in the saga texts. The first one depicts a heathen and probably magic practising, devious villain that typically plays the antagonistic role to the saga hero. This is the case for the dangerous Swedish king Áðils and the legendary Danish hero king Hrólf Kraki who we encounter in Hrólfs saga kraka (fourteenth or fifteenth century). In the characterisation of king Áðils his wealth is emphasised, alluding to a greed for gold is often connected to Swedes (see above Tacitus' depiction of the Suiones). A variation to the 'dangerous' Swede is the depiction of the 'berserk' - a dreaded, ecstatic fighter - as for ex. in Egils saga Skalla-Grímssonar (ca. 1230) (Nedoma, 1990, 52 cited in Donecker, 2002, 31).

The only exception to this generally harsh judgement in the Icelandic and Norwegian texts is that the house of the Svear is ascribed a long life and despite all negative characteristics a great venerability. Furthermore the Swedish kings were the only royal house in Scandinavia that convincingly claimed a divine ancestry. This prestige stemming from heathen times continued to have an effect after Christianisation (Foote, 1993; Müller, 1967; Simek, 1995 cited in Donecker, 2002).

An important contemporary source from outside Scandinavia is the German clergyman Adam von Bremen's Gesta Hammaburgensis ecclesiae pontificum (1075/76) that ascribes the Swedes a great moral integrity, hospitality, fighting abilities and in contrast to Old Norse sources even material modesty. He only disapproves of heathen and polygamous practices he describes. Also towards the other Scandinavian peoples he is generally positive (Adam von Bremen, 2000 cited in Donecker, 2002).

\section{Late Middle Ages}

This period was signified by the Kalmar Union (1397-1523) - a unification of the three Scandinavian kingdoms under the rule of a Danish king. This time was tumultuous and known for its inter-Scandinavian power struggles.

Romanticists and nationalists from the nineteenth and early twentieth century found in this time a wealthy source of persons and events suited for mythification and identity building like the rebel leaders against Danish union kings (even though strongly supported by some Swedish royals) and king Gustav Vasa (founding an independent Swedish kingdom 1523) who became pioneers for (proto) national independence of Sweden. The Swedes were depicted as strong and brave fighters who fought against the tyrannical and greedy Danes. Even though the 
representation of rebellions might induce the idea of a 'Swedish nation' fighting against a suppressing 'Danish nation' there were no consistent ethnic groups of union supporters or opponents. In the Swedish nobility as well as peasantry there were plenty of followers of the Danish rulers (Arnsteber, 1993 cited in Donecker, 2002).

\section{Humanism, Renaissance and Enlightenment}

The participation of Sweden in the Thirty-Years War (1618-1648) led to a hetero-image of the 'cruel Swede' - remembrances of this time are still found in f. ex. German children's rhymes (Gschwandtler, 1999 cited in Donecker, 2002).

The Enlightenment of the eighteenth century devoted itself with great interest to the study of different national characters with scientific approaches. We will discuss some examples in the following sections.

In the context of climate theory ${ }^{3}$ Charles-Louis Montesquieu's Esprit des lois (1748) is an assessment of the physical and psychological effects of the northern climate on its inhabitants that proved to be very influential. In contrast to prevalent opinions he attested the inhabitants of the North to be stronger, more powerful, and disposing of more self-confidence, having thus less inclination towards revenge, suspicion or intrigues. Those clichés acted in favour of the people from Scandinavia, which became a haven of sincerity and freedom (Donecker, 2002).

More hetero-images that actually led to a German-Swedish feud were provided by the German theologian Johann Georg Walch. In the second edition of his Philosophisches Lexicon (1733) he characterized the inhabitants of Sweden and Denmark on basis of the traditional interpretation of the theory of climate. There he attested to their underdeveloped mental faculties, no genius or insight in philosophical questions, fearfulness and as foremost 'passion' parsimony. (See above the parallels in Tacitus and Old Norse sources) A Swedish reaction was published in 1737 in Stockholm: Untersuchung des Temperaments einer gantzen Nation by Johann Friedrich Krüger (the first monograph concerning the Swedish nation). Krüger defended Swedish society in protesting the 'findings' of the climate theory. He pointed out the status of military tradition, judicial and administrative institutions - particularly praising the situation of Swedish farmers, who not only enjoyed personal freedom but in the parliamentary system of the eighteenth century also possessed political power. The latter argument being one of the motives that will dominate the nationalist discourse of the following two centuries, Krüger anchored in the consciousness of the academic elite: the freedom of the Swedish peasantry (Donecker, 2002).

\footnotetext{
${ }^{3}$ A wide spread though very controversial theory amongst enlightenment philosophers which explains the attribution of "folk character", certain typical physical and psychological traits of peoples, according to the climate and environment they live in. Günzel, 2004; Müller,2005.
} 


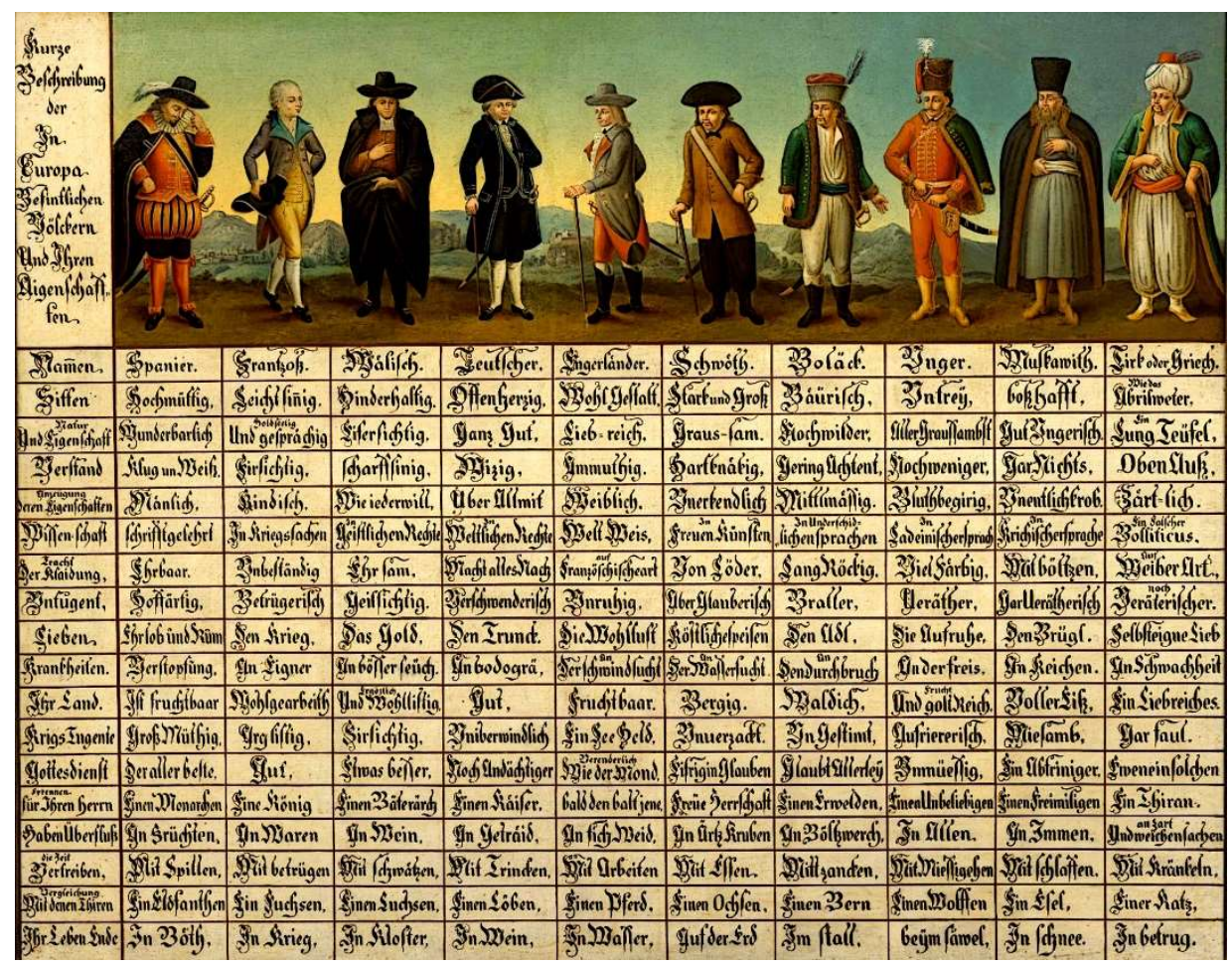

(Figure 2)

The last example of this era, a curious Austrian painting ${ }^{2}$ serves as source of hetero-stereotypes for quite a number of nationalities. The Steirische Völkertafel (ca. 1730/40) (Figure 2) judges 'the Swede' ambivalently: adjectives as 'strong and tall' as well as 'cruel' characterize the Swedes as a typical barbarian people. The prejudice of cruelty reinforces remembrances of the Thirty Years' War. The attested vice of gluttony in combination of mental deficiencies and deficient capacities are ethnographic topoi that go all the way back to antiquity. (See above) The vice of superstition referring to the medieval notion of Sweden as a country of pagans and witches lives on in a modern, enlightened interpretation. Yet positive notions as the militant virtue 'Unverzackt / courageous' (line 11) suggest discipline and perseverance that differs from the image of the impetuous and erratic Germanic tribe. 'Eifrig in Glauben / eager in faith' (line 12) is a surprising compliment, considering that the Völkertafel stems from a Catholic environment (Donecker, 2002; Leersen, 1999).

Despite inconsistencies caused by the transition of Sweden from barbarian clichés to the characteristics of a civilized nation there are constants of Sweden's image in the eighteenth century.

\section{Nineteenth century - auto-images in the North}

In the wake of national romanticism, patriotic intellectuals searched for models in the glorious past. Prior endeavours had been carried out by aristocrats and royalist scholars, whereas now an informal, bourgeois network emerges as carriers of national romanticism: the Swedish centre revolved around 'Götiska förbundet' ('Gothic League') founded in 1811. The centrepiece of Swedish National Romanticism was the figure of the yeoman, who personified the moral strength of the country. An enormous literary and intellectual production was triggered in this time. Examples of famous poems are Erik Gustaf Geijer's Odalbonden (1811) and Vikingen (1811) appearing in the League's journal Iduna. Furthermore (popular) scientific lectures and articles were spreading ideas of national romanticism. This peasant's love for freedom and

\footnotetext{
${ }^{2}$ Steirische Völkertafel, oil painting early eighteenth century, with the title: "Kurze Beschreibung der In Europa Befintlichen Völckern Und Ihren Aigenschafften", Museum für Völkerkunde, Vienna.
} 
strength allegedly stemmed from centuries of struggle with rough nature. The imagined community of the Swedish nation was not only in the sum of its members, but in the unity of people and nature. The alliance between the monarchy and peasantry is at the centre of the national romantic model of society (Donecker, 2002; Stråth, 1995).

Parallel endeavours were undertaken in Denmark most prominently in Grundtvigianism ${ }^{3}$. Stråth writes: 'Grundtvig's Nordic folk high school project was not only a religious movement but also an agrarian movement, the movement of the middle class freeholders. The myth of the free Nordic yeoman peasant was incorporated in the self-understanding of the farmers to strengthen the national community [...]' (Stråth, 1995, 49). Nevertheless, this kind of peasant was historically uncharacteristic.

The emerging questions of Scandinavian nation states and their identity did not only play a role in the respective countries but also on an inclusive Scandinavian level. The movement of 'Scandinavianism' can be considered one of the nineteenth century nationalist integration projects. In contrary to the unification of Italy, the German and Pan-Slavistic plans, that have at least partly been realised, no Scandinavian nation built on Scandinavian identity was established. Stråth explains this outcome with a lack of (supra) ${ }^{4}$ national institutions regulating and organising a Scandinavian society comprising Sweden, Denmark and Norway. Another huge obstacle was the completely different situation in foreign politics, where Sweden had to deal with Russia as a main threat, whereas Denmark competed with Germany (Stråth, 1995).

'The Scandinavian collective myth has existed in a historical literary / poetic romanticist and a modern version' (Stråth, 1995, 400, the prior reviving the Old Norse past with features of an egalitarian peasant society. 'The free and independent Nordic peasant has been a prominent figure in a view of history as a linear evolution from the Viking Age onwards' (Ibidem). These collective myths functioned as confirmative element in national Danish, Swedish and Norwegian identities, contradictorily counteracting the Scandinavian community they embody. Another important key word for Scandinavian identity arose at this time: 'folklighet', which means the identification with the Common People (Protestantism, state authorities, etc.) (Stråth, 1995).

\section{Nineteenth century - hetero-images of the North and German annexion of Nordic past}

In the late nineteenth century the 'North' became incredibly popular in the German Kaiserreich following emperor Wilhelm II in his enthusiasm for the Scandinavian countries. The so-called 'Nordlandromantik' or 'Nordenschwärmerei' of the fin-de-siècle was extremely multifaceted and initially had little to do with the ominous, racial-ideological turn towards the 'Nordic', which played into the hands of the Nazis, who abused the term for their purposes. A German ideology emerged annexing Old Norse literature (medieval) as a proof of a common Germanic past (antiquity), romanticising a further past and Viking age and depicting contemporary Scandinavia as a timeless haven of unhistorical 'genuine' people and nature ignoring actual political and societal conditions. The idealization of the North did serve escapist needs on the one hand and the expansive and aggressive policy of Wilhelm in his battle for supremacy in Europe that made it necessary to mobilize his people ideologically. Some key words describing this 'Germanic / Nordic human' were: 'Noble and proud savage', 'blond and blue eyed', 'healthy and higher evolved race' (Von See, 2003, 40 et seqq.; Henningsen, 1997, 17; Jiresch, 2013, 83 et seqq.; Donecker, 2002, 82 et seqq.).

\footnotetext{
${ }^{3}$ N.S.F. Grundtvig makes often use of a Nordic past in his endeavours to create a Danish identity. His folk education project was based on Danish native language and on the Danish and Nordic history simultaneously aiming at a Christian revival. Stråth, 1995.

${ }^{4}$ Supra - only from the status quo perspective of established nation states.
} 


\section{Twentieth century}

With the rise of social democracy and the birth of the 'folkhem' in Sweden, the orientation towards the glorious past subsides and Swedish society turns towards the future, modern technology, egalitarianism and pragmatism (Donecker, 2002). Sweden adopted a self-image of the moral superpower (in a figurative sense) including an anti-America-position, antiimperialism and engagement for the third world countries, which lasted until the 1990s. As hetero-image this became famously known as the 'Swedish model' amongst others by the American author Marquis Child's book Sweden. The Middle Way (1936) (Donecker, 2002).

Also in the case of the other Scandinavian countries, the peasant past takes a back seat after World War II whereas the egalitarian element gains enormous significance for modern Scandinavianism. Extending the Swedish model to the 'The Scandinavian model' - describing progressive model states for egalitarian welfare - strengthened the idea of a Scandinavian community - even though organised in three states - stemming from the surrounding world as well as from self-reflection (Stråth, 1995).

During the 1980s a crisis of the welfare state, combined with increasing immigration and the debate on membership of the EU, Sweden's self images began to be heavily debated. The intense debate on national identity followed the rules of a popular scientific discourse genre whose trivial content found partially its way into the political debate. This discourse of the late twentieth century focuses around key words like: shyness, reticence, honesty, individualism, love of nature, egalitarianism, moderateness, lack of emotion and logic. ${ }^{5}$

As we have shown auto as well as the hetero images of Scandinavia have changed quite a lot, especially in modernity. In the next part of this article we will if and how these images are appropriated in the online game Dark Age of Camelot. At the same time we will look for traces of Old Norse literature in this game.

\section{Stereotypes in DAoC}

The second part of the article serves to provide examples of the aforementioned stereotypes as well as Eddic themes through a case study of the computer game Dark Age of Camelot (hereafter DAoC).

DAoC is a Massive Multiplayer Online Role Playing Game (MMORPG) created and aired by Mythic Entertainment in 2001. Up to this date, the game is still online. A MMORPG like DAoC is a game played online, together with thousands of other players around the world, online at the same time. At its peak in the year 2005, DAoC reached 250.000 players worldwide (Van Geel, 2013). As is the case with other role playing games, the goal of DAoC is to create a character and move it through the game world. In this game world, the player is free to interact with the game however he or she wants. The character is personalized and has its own various features (like race, gender, profession etc.), and abilities (like strength, magic and speed) (Ensslin, 2012). This character is then used to complete a wide range of different quests and to collect objects. More information on virtual game worlds such as this one can be found in the description of E. Castronova (2005). The goal of games like DAoC is mainly to train your character and obtain a higher level while exploring an online world, the player is however free to do what he or she wants when exploring the virtual word (Castronova, 2005). As a fantasy game, many of the motifs and themes in the game correspond to the fantasy megatext, which originally revolves around Tolkien's Lord of the Rings, and later on fantasy games such as Dungeons \& Dragons (Canavan, 2011). In the analysis below, the focus will be less on the links between this fantasy megatext, and more on links towards Norse mythology. The game is set in a fictitious world consisting of three realms fighting for dominance: Albion, Hibernia and Midgard. The inhabitants of the realms are respectively based on Anglosaxon, Celtic and Norse

\footnotetext{
${ }^{5}$ Donecker points out Åke Dauns study Svensk mentalitet (1989) as one of the more reliable and scientifically corroborated works dealing with Swedish self images. Donecker, 2002.
} 
medieval tradition and mythology. (Broadsword a, 2014) Below we will first discuss in what way the above-mentioned stereotypes are perpetuated in DAoC. After that, we will compare the motives used in the game with the Edda's and show where and how the developers have appropriated themes taken from Eddic texts. A similar analysis could off course be conducted for the realms of Albion and Hibernia and the mythologies the two are based on.

In this section, we will first have a look at the general information that is provided by the website, in order to set the scene of the game world and its inhabitants. According to these descriptions and further in-game information, the inhabitants of Midgard are:

generally stocky in build, strong and not quite as civilized as inhabitants of the other realms. However, when it comes to fighting, the Norse are equalled by none. [...] The Norse races are the standard human viking, the large strong troll, the short hardy dwarf, and the small crafty kobold. [...] The vikings are the humans of Midgard, and as such are tall, hale, hardy, but generally not quite as civilized as humans from other realms. [...] We all look at the lands of Hibernia and Albion with some eagerness and hunger. [...] Our weapons are sharp, our warriors fearless and we carry the gods' own magic in our hearts as we well as our swords an axes (Broadsword b, 2014).

Many of the aforementioned stereotypes come together to describe Midgard's inhabitants. The notion of Vikings being the "standard" of Nordic humans focuses clearly on the hetero conceptions made from humanism until nationalism. The prime auto image being the free peasant is nevertheless not mentioned in the game at all. The characteristics "fearless" and "not quite as civilized" can even be traced back to antiquity. The mentioning of a heathen belief system and magic could even be found in Old Norse source, hetero stereotypes referring to the late Christianized Swedes.

\section{Eddic themes in DAoC}

In this section, we will shed light on the way the game uses themes that can be traced back to the Edda's. When it comes to these Eddic themes in DAoC, there are multiple ways these come to the surface. There are,for example, different mythological inspired races and classes ${ }^{6}$ a player can choose from when creating a character. Each race and class comes with its own advantages and abilities. As a player choosing to play for the realm of Midgard, this means that you can choose between seven different races when creating your character. These seven are: Kobold, Dwarf, Norsemen, Troll, Valkyn, Frostalf and Minotaur. After this, the player can choose between fifteen different classes. For Midgard, these classes are Berserker, Bonedancer, Healer, Hunter, Mauler, Runemaster, Savage, Shadowblade, Shaman, Skald, Spiritmaster, Thane, Valkyrie, Warlock and Warrior. Below we will further examine the races 'Dwarf', 'Frostalf' and 'Norsemen' and the classes 'Thane', 'Runemaster' and 'Valkyrie'.

\footnotetext{
${ }^{6}$ By choosing a class, the player actually chooses the character's abilities and for example the kind of weapon he or she uses. In other words, the different classes can be seen as some kind of career path, as every class results in a different playing experience.
} 


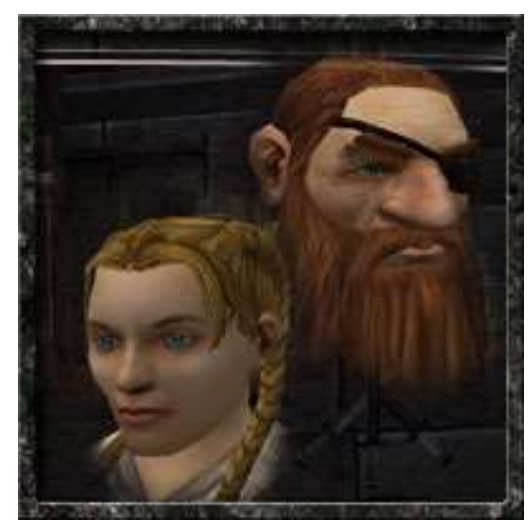

(Figure 3 Dwarves)

The Dwarves in DAoC come from Haggerfell and are said to be "strong in their devotion to the elder gods and the finer ales" (Broadsword c, 2014). The dwarves are said to be the fundament of the armies of Midgard. Before the battle for the three realms began, they lived underground. They decided to come to the aid of Midgard and leave their cities below the ground behind. (Broadsword c, 2014)

In Snorri Sturluson's The language of poetry (Skáldskaparmál), one reads that it is possible to refer to poetry as for example 'Dwarves mead' (Faulkes, 1995, p. 70) This form of referring is called a 'kenning', a poetic style figure unique for Old Norse literature, where something is described by a poetic metaphor. It might be a reason why Dwarves often are associated with the drinking of a lot of alcohol in popular culture like for example J.R.R Tolkien's Lord of the Rings (Tolkien, 2007).

The following verse of The ballad of Alviss (Alvíssmál) shows us that dwarfs in the Edda's can't show themselves on the surface without turning to stone in the sun light:

In a single breast I never have seen

More wealth of wisdom old;

But with treacherous wiles must I now betray thee:

The day has caught thee, dwarf!

Now the sun shines here in the hall.

(Bellows, 1936, pp. 193-194)

The Dwarves in DAoC are said to have left their dark halls underground to join the battle. However, in the Poetic Edda one can read how Alvíss turns to stone in the sun, suggesting that dwarves cannot live in the sunlight.

When we finally look at the way the dwarves are depicted in the game, we see that the male version has a blind left eye and wears an eye-patch. This reminds of how Odin gave up one of his eyes at Mimirs well in order to gain more wisdom. About this event, one can read in The Wise Woman's Prophecy (Völuspá), verse 29 (Bellows, 1936). 


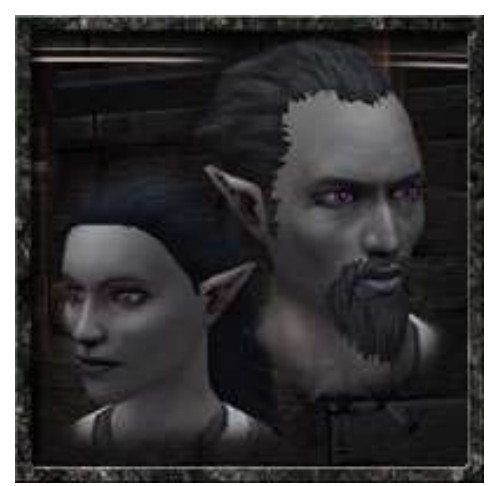

(Figure 4 Frostalf)

The second example of an Eddic inspired race is the Frostalf, although half of this races' background story is made up by the creators of the game, it is still interesting for us, as the Frostalfs are said to have their background in the Svartalfs. (Broadsword d, 2014) Once upon a time, there were two princes; the twins Hauk and Enar. It is said that after the deaths of their parents, they could not decide who should rule in their stead. As a result of the conflict that followed, Hauk and his followers left the realm of Svartalfs and settled in the cold and dark realm of Niflheim. Generations later they came to be known as the Frostalfs. (Broadsword d, 2014) The Frostalfs in DAoC are presented as creatures with a natural high piety, black skin and pointy ears. (Broadsword d, 2014) Of special interest here is the fact that the way the Frostalfs are depicted in the game (figure 4) corresponds to the way the Svartalfs are described in the Edda's, that is with black skin and pointy ears. Looking at the Frostalfs as Svartalfs gives us the possibility to look for them in the Edda's, where we for example find the following in The tricking of Gylfi (Gylfaginning):

That which is called Álfheimr is one [realm], where dwell the peoples called Light-Elves; but the Dark-Elves dwell down in the earth, and they are unlike in appearance, but by far more unlike in nature. The Light-Elves are fairer to look upon than the sun, but the Dark Elves are blacker than pitch (Faulkes, 1995, pp. 19-20).

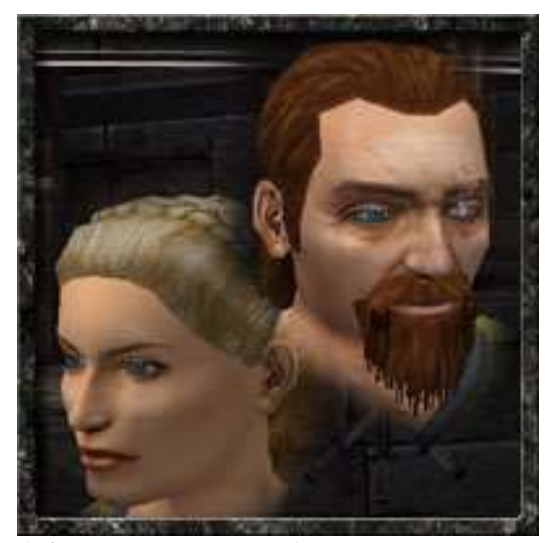

(Figure 5 Norsemen)

The final race we would like to elaborate on here are the Norsemen (figure 5), who are presented as 'the common men and women of Midgard.' (Broadsword f, 2014) They are said to be 'tall and strong', as well as 'very adaptable'. The stereotypes presented on the Völkertafel "partly return in this description (the Norsemen are 'strong and tall'). Notice the blind eye of the man in the image, which yet again might be perceived as a reference to Odin giving one of his eyes for wisdom. Apart from this, notice the blond hair and blue eyes of the female. Yet again a stereotype is returning to the game, this time going back to ancient sources like Tacitus. 
When it comes to the Edda's, there are several examples of human heroes. Also here, there is word of Nordic peoples being tall and strong, as we can read in Völsunga Saga, Of the Semblance and Array of Sigurd Fafnir's-bane:

And this is the sign told of his height, that when he was girt with his sword Gram, which same was seven spans long, as he went through the full-grown rye-fields, the dew-shoe of the said sword smote the ears of the standing corn; and, for all that, greater was his strength than his growth (Morris \& Magnusson, 2001, p. 115).

Apart from these races that seem to have been inspired by the Edda's, there are other examples that find no parallel in the Edda's. Possibly the best example in this category is the Minotaur. This creature does not have its origins in Norse, but in Greek mythology. The Minotaur is the only race available for all three realms. The Norse version of the Minotaur is characterized by the fact that they are more savage and fierce than their kin in the other realms, and have battle scars and eye-patches (Broadsword e, 2014). One cannot help to think back to the stereotypes presented above.

\section{Classes}

Other examples of mythological motives are found in the different classes available in DAoC, where most classes are represented by one of many Norse deities. An example of such a class is the Thane class.

The Thane class is inspired by the god Thor. Basically, a character that chooses the Thane class is a worshipper of 'the Norse God of Thunder and Lightning' (Broadsword g, 2014). The game calls Thor one of the most famous gods because of the way he protects Midgard with his 'mighty hammer Mjölnir' and 'the power of the storms rage' (Broadsword g, 2014). By worshipping Thor, the player's character obtains the power to use the power of storms. He or she can shoot lightning at his or her opponent (Broadsword g, 2014).

When we compare the portraying of Thor in the game and the Edda's we see that there are multiple examples of Thor defending Midgard. One of these examples is found in The Lay of Hymir (Hymiskviða), verse 23, where Thor defeats the Midgard serpent with his hammer:

'The venomous serpent swiftly up

To the boat did Thor, the bold one, pull;

With his hammer the loathly hill of the hair

Of the brother of Fenrir he smote from above.' (Bellows, 1936, p. 146)

In The Lay of Thrym (Prymskviða) (Bellows, 1936) one reads how Thor needs his hammer Mjölnir for his strength and to protect Midgard.

When it comes to the power to control thunder and storms, there are no clues in the Edda's that point out that Thor would have any such abilities. Basically what is the case here is that the creators of the game seem to have used one of the Norse gods as a motif, and passed on the god's power to his worshippers. They also gave the deity extra powers that do not originate from the Edda's.

A different example is the Runemaster class. Contrary to what we have seen above, this class is not represented by a deity, but rather characterized by the way it uses objects (in this case runes) as their source of power. The in-game information describes the runemaster as a warrior who 'smites foes from great distances with vast amounts of power and wrecking pain.' (Broadsword h, 2014) They are said to 'fashion their powerful spells from ancient runes used by the Mystics of Midgard.' The runes are here described as 'the absolute source of power' of a runemaster (Broadsword h, 2014). 
Examples for this way of using runes as a source of power are also found in the Edda's. One of these is found in The Ballad of The Victory-Bringer (Sigrdrifumál), verse 6:

Winning-runes learn, if thou longest to win,

And the runes on thy sword-hilt write;

Some on the furrow, and some on the flat,

And twice shalt thou call on Tyr. (Bellows, 1936, p. 391)

Here the valkyrie Sigrdrifa tells Sigurd how learning about the different runes could be of help to him in various situations. Apart from that, she also tells him that he has to call upon the deity Tyr in order for the runes to work. This could however also be interpreted as if he is told to use the T-rune twice.

A different example, where this calling upon a deity is not apparent, is found in The Lay of Helgi the Son of Hjorvarth (Helgakviða Hjörvarðssonar), verse 29:

Look eastward, Hrimgerth, for Helgi has struck thee

Down with the runes of death;

Safe in harbor floats the prince's fleet,

And safe are the monarch's men. (Bellows, 1936, p. 283)

Here the runes are clearly used as a form of weapon by Helgi. By striking Hrimgerth with runes of death he has won the battle and made it ashore safely.

It needs to be mentioned that the so called 'Mystics of Midgard' who, according to the game, first used the ancient runes, are nowhere to be found in the Edda's but are a product of the developers imagination. The examples above show us that the Edda's might have been a form of inspiration for the game developers of the game.

The last class we would like to mention here is the class of the Valkyries. In Norse mythology, the valkyries are said to be the ones who helped Odin choose which soldiers would die on the battlefield and come to Walhalla. There are multiple poems that refer to the valkyries, such as The Wise Woman'sProphecy (Völuspá), verse 31:

On all sides saw I Valkyries assemble,

Ready to ride to the ranks of the gods;

Skuld bore the shield, and Skogul rode next,

Guth, Hild, Gondul, and Geirskogul.

Of Herjan's maidens the list have ye heard,

Valkyries ready to ride o'er the earth. (Bellows 1936, p. 14)

In this verse, the 'valkyries ready to ride o'er the earth' are the valkyries that are ready to fly over the battlefield and pick out the death for Walhalla. Herjan's maiden is a different name for valkyries, originating from the fact that the Valkyries help Odin to take the fallen soldiers to Walhalla. He is called 'Herjan' here, which could be translated with something such as 'the Lord' (own translation). Note, however, that translation of names differs from translation to translation. Otten for example calls him 'Krijger', meaning warrior.

In The Tricking of Gylfi (Gylfaginning), Snorri Sturluson writes that the valkyries are the ones 'Odin sends to every battle; they determine men's feyness and award victory.' (Faulkes, 1995, p. 31)

The Valkyrie class in DAoC is called the 'Order of the Valkyries' and is said to be started by Sigrun and Brynhild, two beautiful orphaned sisters. (Broadsword i, 2014) Both claim to have been able to hear the voices of the dead speaking to them from Walhalla their entire life. These 
voices told them about a great war that would soon strike down upon Midgard. (Broadsword i, 2014) The two sisters were ordered to start the Order of the Valkyries to lead the defenses of Midgard against the other two realms. An interesting fact is that only female characters can join the valkyrie class (Broadsword i, 2014).

One might recognize the names of both Sigrun and Brynhild. Both are mentioned in the Edda's. They are not, however, sisters. Sigrun was the daughter of Hogni and, according to The Second Lay of Helgi Hundingsbane (Helgakviða Hundingsbana önnur), 'she was a Valkyrie and rode air and water; she was Svava reborn' (Bellows, 1936, p. 313). Brynhild was the daughter of Budli and wife to the hero Sigurd as one can read in Gripir's prophecy (Gripisspá) (Bellows, 1936, pp. 337-355). In Snorri Sturluson's Prose Edda, Brynhild is mentioned as a valkyrie. For this, see The Language of Poetry (Skáldskaparmál) where it is written how Sigurd found Brynhild in a house on a mountain (Faulkes, 1995). As for the claim that they both heard voices coming from Walhalla, which triggered them to start the order of the Valkyries (in other words become Valkyries), we can say that this is not corresponding to the Edda's. In the Edda's the valkyries are the helpers of Odin and decide for him who should be allowed entrance into Walhalla, as we have seen above in the citation from The Tricking of Gylfi (Gylfaginning) (Faulkes, 1995).

Here we can see that this is another way of using a motive from the Edda's to create a class in DAoC. The creators of the game used the concept of the valkyries along with two known names from the Edda's and created their own version of the Valkyrie.

\section{Concluding Remarks}

After outlining the images and stereotypes of the inhabitants of Northern Europe / Scandinavia in a historical overview, we showed their appropriation in the online game DAoC. Furthermore, themes and characters taken from Eddic texts have been a great source of inspiration for the game's developers as we have shown in various examples.

To summarize: some hetero stereotypes of Nordic people dating back to antiquity and medieval times are still reiterated in DAoC and proven hereby their enormous persistence. This should be an incentive for further research on the appropriation of those images in the new media.

Nevertheless, do those stereotypes play a minor role in the game compared to Eddic themes and characters. Therefore, it is safe to say that the developers have appropriated the actual medieval texts in a greater degree than they have used the abovementioned stereotypes.

\section{Bibliography}

Arnstberg, K.-O. (1993). Den klagande svensken. Stockholm.

Aronson, E., Wilson, T.D. \& Akert, R.M. (2005). Social psychology. New Jersey: Upper Saddle River.

Beller, M. \& Leerssen, J. (2008): Imagology: The cultural construction and literary representation of national characters. A critical survey. (=Studia imagologica 13) Amsterdam: Rodopi.

Bellows, H. A. (1936). The Poetic Edda. Princeton: University Press.

Cederschiöld, G. (1899). Om Erikskrönikan: Ett historiskt epos från Folkungatiden. (= Populärt vetenskapliga föreläsningar vid Göteborgs Högskola 11) Göteborg.

Canavan, A-P. (2011). Looting the Dungeon: The Quest for the Genre Fantasy Mega-Text. Liverpool: University of Liverpool

Castronova, E. (2005). Synthetic Worlds: The Business and Culture of Online Games. Chicago: University Press. 
Donecker, S. (2002). Mutter Sveas unsanftes Erwachen. Genetisch-interpretative Annäherung an den gegenwärtig in Schweden geführten nationalen Diskurs. Universität Wien: Unveröffentlichte Diplomarbeit.

Ensslin, A. (2012). The Language of Gaming. Basingstoke: Palgrave Mcmillan.

Faulkes, A. (1995). Edda: Snorri Sturluson. London: Dent.

Foote, P. (1993). Icelandic historians and the Swedish image. Comments on Snorri and his precursors. In G. Dahlbäck (Ed.), Snorre Sturlasson och de isländska källorna till Sveriges historia. Fyra föreläsningar från ett symposium i Stockholm hösten 1988 (pp. , 9-42). Stockholm: Sällskapet Runica et Mediævalia.

Goffart, W. (2005). Jordanes's "Getica" and the Disputed Authenticity of Gothic Origins from Scandinavia. Speculum, 80 (2), 379-398.

Gschwandtler, O. (1999). Stereotype, historische Erfahrung und aktuelles Wissen im Schwedenbild der Völkertafel. In F. K. Stanzel et al. (Eds), Europäischer Völkerspiegel. Imagologisch-ethnographische Studien zu den Völkertafeln des frühen 18. Jahrhunderts (pp. 225-249). Heidelberg.

Günzel, S. (2004). Geographie der Aufklärung. Klimapolitik von Montesquieu zu Kant (Teil 1). Aufklärung und Kritik. Zeitschrift für freies Denken und humanistische Philosophie 11, 22, 66-91.

Henningsen, B. (1997). Das Bild vom Norden. Eine Einleitung. In B. Henningsen et al. (Eds), Wahlverwandtschaft: Skandinavien und Deutschland 1800 bis 1914 (pp. 15-27). Berlin: Jovis.

Henningsen, B. (Ed.) (2002). Das Projekt Norden: Essays zur Konstruktion einer europäischen Region. (=Wahlverwandtschaft: Der Norden und Deutschland: Essays zu einer europäischen Begegnungsgeschichte 9) Berlin: Spitz.

Hellquist, E. (1980). Svensk etymologisk ordbok. Första bandet A-N. Lund: Liber Läromedel.

Jiresch, E. (2013): Im Netzwerk der Kulturvermittlung: Sechs Autorinnen und ihre Bedeutung für die Verbreitung skandinavischer Literatur und Kultur in West- und Mitteleuropa um 1900. Groningen: Barkhuis.

Leerssen, J. (1999). Nationaal denken in Europa: Een cultuurhistorische schets. Amsterdam: University Press.

Lönnroth, L. (1986). Dómaldi's death and the myth of sacral kingship. In J. Lindow et al. (Eds), Structure and Meaning in Old Norse Literature. New Approaches to Textual Analysis and Literary Criticism (pp. 73-93). Odense: University Press.

Morris, W. \& Magnusson, E. (2001). The Volsunga saga. London: Electric Book Co.

Much, R. (1959). Die Germania des Tacitus. Heidelberg: utan förlag.

Müller, K. (1967). Der Beginn eines Volks- und Staatsbewusstseins im Norden. Das politischethnische Selbstverständnis der Nordleute in Wikingerzeit und beginnendem Mittelalter. Phil. Diss. Göttingen.

Nedoma, R. (1990). Gautreks saga konungs. Die Saga von König Gautrek. (Göppinger Arbeiten zur Germanistik 529). Göppingen: Kümmerle.

Guðmundsson, F. (Ed.) (1965). Orkneyinga saga (ca. 1200). Legenda de Sancto Magno. Magnúss saga skemmri. Magnúss saga lengri. Helga páttr ok Úlfs. (=Íslenzk fornrit 34) Reykjavík: Hið Íslenzka fornritafélag.

Østergård, U. (1997). Nationale Identitäten. Ursprünge und Entwicklungen: Deutschland, der Norden, Skandinavien. In B. Henningsen, J. Klein \& H. Müssener (Eds), Wahlverwandtschaft: Skandinavien und Deutschland 1800 bis 1914 (pp. 29-37). Berlin: Jovis.

Sawyer, B. \& Sawyer, P. (1993). Medieval Scandinavia. From Conversion to Reformation circa 800-1500. (=The Nordic series 17) University of Minnesota.

Simek, R. (1995). Lexikon der germanischen Mythologie. Stuttgart: Kröner. 
Simek, R. \& Palsson, H. (1987). Lexikon der Altnordischen Literatur. Stuttgart: Kröner.

Tolkien, J.R.R. (2007). The Lord of the Rings. London: HarperCollins.

Von Bremen, A. (2000). Magistri Adam Bremensis Gesta Hammaburgensis ecclesiae pontificum. In W. Trillmich \& R. Buchner (Eds), Fontes saeculorum noni et undecimi historiam ecclesiae Hammaburgensis necnon imperii illustrantes (=Ausgewählte Quellen zur deutschen Geschichte des Mittelalters 11) (pp. 135-503). Darmstadt.

Von See, K. (2003). Texte und Thesen. Streitfragen der deutschen und skandinavischen Geschichte. (=Frankfurter Beiträge zur Germanistik 38) Heidelberg: Winter.

Von See, K. (1999). Europa und der Norden im Mittelalter. Heidelberg: Winter.

\section{Online sources}

Broadsword a. 'Three realms'. (2014) on: http://darkageofcamelot.com/content/three-realms (last accessed: 27 august 2015).

Broadsword b. (2014). 'Midgard' at: http://camelotherald.wikia.com/wiki/Midgard (last accessed: 27 August 2015).

Broadsword c. (2014). 'Dwarf' at: http://camelotherald.wikia.com/wiki/Dwarf (last accessed: 27 August 2015).

Broadsword d. (2014). 'Frostalf' at: http://camelotherald.wikia.com/wiki/Frostalf(last accessed: 27 August 2015).

Broadsword e. (2014). 'Minotaur' at: http://camelotherald.wikia.com/wiki/Minotaur (last accessed: 27 August 2015).

Broadsword f. (2014). 'Norsemen' at: http://camelotherald.wikia.com/wiki/Norseman (last accessed: 28 August 2015).

Broadsword g. (2014). 'Class library: Thane' at: http://darkageofcamelot.com/content/classlibrary-thane (last accessed: 27 August 2015).

Broadsword h. (2014). 'Class library: Runemaster' at: http://darkageofcamelot.com/content/class-library-runemaster (last accessed: 27 August

2015).

Broadsword i. (2014) 'Class library: Valkyrie' at: http://darkageofcamelot.com/content/classlibrary-valkyrie (last accessed: 27 August 2015).

Miller, W.I. (2014). 'Why is your axe bloody?'. A Reading of Njàls Saga. Oxford Scholarship Online. http://www.oxfordscholarship.com.proxy-ub.rug.nl/view/10.1093/acprof:oso/ 9780198704843.001.0001/acprof-9780198704843-chapter-23 (last accessed: 30 august 2015).

http://www.ne.se/uppslagsverk/encyklopedi/1\%C3\%A5ng/g\%C3\%B6tar (last accessed: 20 August 2015).

Van Geel, I. (2013). 'Subscription and active accounts with a peak between 150k and 1m' at: http://users.telenet.be/mmodata/Charts/Subs-2.png (last accessed: 30 August 2015).

\section{Biographical note}

Ester Jiresch is Senior Lecturer for European Culture and Literature (Swedish) at the Chair of European Culture and Literature of the University of Groningen. She received her PhD at the Groningen Research School for the Study of the Humanities at the University of Groningen, on the role of networks in the work of female cultural transmitters of Scandinavian literature and culture in Europe around 1900 - comparing the Dutch/Flemish and the Austrian/Germanspeaking regions. Her research interests include cultural transmission, gender studies, Swedish culture and literature, interdisciplinary research Humanities-Social Sciences (applied Political Science). 
Vincent Boswijk holds a MA in Multilingualism and a BA in Scandinavian languages and cultures. He is currently conducting $\mathrm{PhD}$-research in the field of Culture, Language and Technology at the University of Groningen. 